\section{GATEWAYS OF SCIENCE}

$I^{\mathrm{N}}$

$\mathrm{N}$ his presidential address to Section $\mathrm{X}$ (Assembly of Corresponding Societies), Dr. W. E. Swinton directs attention to the history and function of the new Assembly as descendunt of the Conference of Delegates and contrasts them with those of other sections and the Association as a whole. He regards the meeting of the whole Association as the remnant of what was once tantamount to the annual meeting of the shareholders interested in national, if not nationalized, science-the remnant, because only a small part of the sectional business is nowadays within the comprehension of the general public, which is numerously represented in the annual meeting. In the circumstances, he feels that the Assembly has the duty of catering for many of these interested laymen and of reaching out beyond the annual meeting to the great masses of people who have a right to know about scientific plans and progress.

This is the more essential since it is becoming widely realized that the starting and maintenance of a scientific process or programme is only the beginning of a chain of events that might have great political and ethical results as well as intellectual by-products. Prof. A. V. Hill, at Belfast, directed attention to the dilemmas of science, to the need for orientation and re-orientation of its progress, and the members of the general public have a right to know, as beneficiaries or as victims, where they are likely to stand in the composite picture. There are also the many who follow science, as Sir Edward Appleton has shown, for its own sake.

The Assembly is the inheritor of a rich history of collaboration with the societies which, year after vear, fight a battle, sometimes a losing one, for better public understanding of science, especially archæology and natural history. Many of these societies are old; it might be thought that the fight is no longer serious, that generally the recognition of so-called scientific truths is assured. Yet it is not so in many highways and byways; one does not have to work long in a museum or to give many broadcast talks to realize that the truths themselves are challenged, that the "Origin of Species" which sought to emphasize the rise of man is frequently interpreted as a sign of his fall. The biological study of man, it might be contended, has lowered his stature. Although the publication of Darwin's great work was an. intellectual milestone, executions in England were still carried out in public for ten years after its first appearance; but there are many other better known social and medical facts which support the contention that the increase of biological knowledge has gone hand in hand with an increase in man's prestige.

To satisfy adequately the just demands of the general public calls for a rearrangement of the Assembly's outlook. There must be an increase in facilities for both the young and the not so young to have the best advice in scientific career factfinding. Here the rich stores of experience in the Association should be tapped. There must also be increased facilities for the flow of authoritative information to the general public, individually or in groups of adult students.

The existing facilities in science for adults include : the libraries, museums, societies, the Workers' Educational Association, the B.B.C., and other bodies. It is clear from a conservative study of the figures available that there are thousands of persons almost habitually unable to attend the British Association moetings who are none the less well within the range that the Association desires to serve. In these circumstances a new form of membership-a corresponding membership-should be considered. This could be arranged so that aspirants to professional education and entry to the scientific services can have the advice they need. On the other hand, he outlines the kinds of services, reading lists and guidance in studies in and out of doors that could be given to adults and study groups. None of this need conflict with existing services but could be collated with and amplify them, and more immediately govern their trends.

Such a programme is important and will become increasingly so. It is important to consider the matter on a high level, and Dr. Swinton suggests a surveying committee to review and prescribe methods of co-operation between the British Association, Library Association, the Museums Association, the Unions of Scientific Societies, the Workers' Educational Association, the Further Education Section of the B.B.C. and representatives of the education authorities.

This would at least ensure the continuance of the great interest in the British Association's work and ideals which adults and the young, the regional and local education authorities, and many other responsible bodies have so abundantly demonstrated in Belfast and Liverpool. With it the gateways of science should be more freely opened.

\title{
OBITUARIES
}

\section{Dr. M. H. Gordon, C.M.G., C.B.E., F.R.S.}

WIrr the death of Dr. M. H. Gordon, on July 26, aged eighty-one, British bacteriology has lost one of its outstanding figures, while the world mourns the passing of one who did good to all men. His work, much of which was that of a pioneer, has been deeply appreciated in his own country, and indeed throughout the world, by his professional brethren; but it is not primarily as an exponent of his profession that Gordon will be remembered by those who had the good fortune to be his friends-he will live in their memory because of his personal qualities, his geniality, his enthusiasm, his understanding and, in a very special way, for the kindness he showed to junior colleagues, many of whom owe to him a real debt of gratitude because of the encouragement given to them by him in their formative years. Widely read in many subjects far remote from his chosen speciality-literature, the fine arts and, above all, history-Gordon's companionship was both stimulating and satisfying. He inherited from his Scottish ancestors a liking for controversy, and an evening spent with him, enlivened by argument often acute but never bitter, was an unalloyed pleasure: he was one of those rare souls with whom one could agree to disagree and remain a firm friend.

Gordon's active life as bacteriologist and immunologist covered almost a half-century in which profound 